CASTE: A Global Journal on Social Exclusion

Vol. 1, No. 2, pp. 73-90

October 2020

ISSN 2639-4928

DOI: 10.26812/caste.v1i2.171

\title{
Speaking is Healing: Dalit Women Gain a Voice through a Charismatic Healing Movement in Nepal
}

\author{
Amar Bahadur BK'
}

\begin{abstract}
The concept of voice has been central to Dalit studies as well as in other studies such as feminist, subaltern, and social movement studies. These studies have conceptualized voice as an expression of agency and empowerment. They have paid more attention to voice's agentive capacity, and have thus ignored the materiality of voice; for example, the act of speaking itself. Based on my ethnographic fieldwork on a charismatic healing movement called Sachchai (truth and/or reform) participated predominantly by Dalit women in Pokhara, Nepal, this article examines why even ordinary acts of speakingirrespective of the content-matters so much for marginalized women. Dalit women mainly join Sachchai to heal their illnesses and sufferings and address other everyday problems. Nonetheless, the testimonial and Bible speeches they deliver in Sachchai devotional meetings during the processes of healing allow them to build their confidence and to learn to speak. The ability to speak-as ordinary as telling their name in public, speaking to a stranger or a government official, holding a microphone-becomes a remarkable achievement for these women. The speaking itself is considered as the evidence of healing from their illnesses and suffering. This article, thus, argues that paying attention to speaking itself is crucial for a fuller understanding of voice. While focusing on the act of speaking, this article does not undermine Dalit Sachchai women's agency; rather it intends to expose the plight of Dalit women, for whom just uttering their name in the public is a great feat.
\end{abstract}

\section{Keywords}

Voice, charismatic healing, Dalit women, caste, gender, Nepal, Sachchai

'Department of Anthropology, University of Pittsburgh, Pittsburgh, USA

E-mail: abb60@pitt.edu

(C) 2020 Amar Bahadur BK. This is an open access article distributed under the terms of the Creative Commons Attribution License, which permits unrestricted use, distribution, and reproduction in any medium, provided the original author(s) and source are credited. 


\section{Introduction}

Dressed in clean clothes, her hair combed, and face slightly made-up, Asha ${ }^{1}$ came to her parents-in-law's house one Saturday morning in the summer of 2016. Asha entered the house and fetched a loudspeaker, electric cables, batteries, and a few microphones to the backyard where she cleaned the apparatus with a piece of cloth and checked the sound. A little while later, Asha's husband arrived, and while she was talking to me, he cleaned the backyard of the house and positioned the loudspeaker, connected it to the microphone with cables, fetched a few benches and chairs, and unrolled a plastic carpet on the ground.

Soon women started arriving one by one, holding their babies and with toddlers in tow. About thirty in number and belonging mostly to low or Dalit castes, they sat cross-legged close to each other on the carpet, with a Bible on their laps. The women had gathered, as I later learned, for a weekly satsang (devotional gathering) of a charismatic healing movement called Sachchai (truth and/or reform). Asha led and managed the branch of the movement in her village. The satsang ran for three hours during which the women prayed, sang bhajans or hymns, narrated gawai (testimonies), and delivered bachans (edifying speeches), all of which were amplified by the loudspeaker, and could be heard several hundred meters away. More than anything else, what astonished me was the confident and fluent speeches of these women, who are mostly illiterate farm labourers, and housewives. Until a few years ago they would even hesitate to talk to a stranger or, to talk in a public place. A barely literate and a low-caste woman, Asha, herself spoke for about an hour.

She again showed up at the house later that evening for some work with her motherin-law. She was eager to hear my impression about the satsang and, particularly, the speech she had delivered in the morning. I said her speech was nice. 'I had seen you capture the video of my speech. Does it look good?' asked Asha. She was interested to see the video, and after watching it, she said she felt a bit embarrassed to see herself on video. She compared herself now and six years ago when I first met her: 'You know I used to be shy even to talk to you. Now I can speak with anyone and before any number of people.' Asha told me that her ability to speak holding a microphone was the biggest achievement in her life.

Why has the ability to speak holding a microphone-irrespective of what they say-become a significant achievement for Asha and thousands of other Dalit women, who have embraced Sachchai? Is their speaking at these gatherings a medium of communicating with God? Or, does it represent something else? What does it tell us about the predicament of Dalit women in contemporary Nepal? In this article, I am going to show why the act of speaking itself, rather than 'voice' as it is usually understood by scholars in the sense of agency and empowerment, is significant for marginalized people such as Dalit Sachchai women. For lay observers, Sachchai women's speaking through a microphone might seem nothing extraordinary. However, both caste and patriarchy ${ }^{2}$ have muted and continue to mute not only Dalit women's political expression and power, but also the sound of their voices. ${ }^{3}$ Therefore, if we examine activities at Sachchai through Nepal's historical and cultural contexts, Dalit Sachchai women's speaking looks meaningful.

The purpose of this article is two-fold. First, building on the theories in religion and media studies that consider media such as the religious speaking in Sachchai as serving communicative functions, I am going to show how religious speaking can 
itself be an end goal, and not a medium. Scholars of religion and media take media, particularly religious sounds such as loudspeakers, music, and speeches, as a form of mediation or a communicative genre (De Vries, 2001; Hirschkind, 2006; Meyer, 2010). For example, Birgit Meyer (2010, p. 750-51) considers the role of media in Pentecostalism as 'aesthetic persuasion.' The persuasive role of Dalit Sachchai women's edifying speeches cannot be denied. But my ethnography shows that speaking through a microphone, for them, is not just a means of expression, but is an end in itself -a way of realizing dignity and self-respect. More than just using a microphone and giving speeches as a medium through which empowerment may be achieved, they gain a voice through the very act of speaking.

Secondly, building on the recent literature that criticizes dominant conceptualizations of voice and pays attention to the materiality of a voice or the sound of a voice (for example, Dunn \& Jones, 1994; Hirschkind, 2006; Taylor, 2009; Weidman, 2006), this article will show how paying attention to the act of speaking itself, the sound of a voice and sound technology such as microphone can enhance our understanding of voice.

In the pages that follow I first briefly introduce the Sachchai movement in Nepal. I then explore, in the next section, how Dalit Sachchai women learn to speak in Sachchai satsangs. I show how women build their confidence to speak in various ways such as through the power of the divine that they receive, and the social and emotional support they get from fellow women believers, and the community of listeners Sachchai provides. In the succeeding section, I explain the symbolic meaning that holding a microphone carries for these women. Microphones symbolize prestige and empowerment for these women. Thereafter, I will dwell on what speaking means for Sachchai women. I will also seek to explain how and why they consider their speaking as evidence of their healing from illnesses, pain, and suffering. I conclude by explaining why giving attention to the acts of speaking enhances our understanding of voice.

\section{The Sachchai Movement in Nepal}

This article is based on two years of ethnographic fieldwork conducted between 2016 and 2019 on a charismatic healing movement called Sachchai in the city of Pokhara and its surrounding villages in Nepal. I observed hundreds of Sachchai satsangs, listened to hundreds of testimonies, held in-depth interviews with 50 women 'believers' (mostly Dalit women), and had informal conversations with dozens of them. There are many competing groups within the Sachchai movement, with at least half a dozen groups in Pokhara alone. My fieldwork focused on one group, the largest group, of the movement called Ishwariya Bhajan Mandal Sachchai Kendra Nepal (Divine Psalm Ministry Sachchai Centre Nepal). This group alone has more than one hundred branches across the predominantly Hindu landlocked country in the Himalayas.

Sachchai is a relatively new religious movement, one among various competing faith-based organizations/movements in Nepal. ${ }^{4}$ It started at the beginning of the twenty-first century, and then rapidly expanded across towns and villages in the country. Sachchai now has hundreds of branches and hundreds of thousands of followers in Nepal. ${ }^{5}$ Nepal's social, political and economic contexts in the last two decades provided fertile ground for Sachchai's rapid expansion: the decade-long Maoist civil war ended in 2006 and Nepal became a secular state and the period 
after the war was marked by extreme political instabilities, huge international labour migration of men, dire lack of public goods and services, and, most importantly, rising domestic violence against women.

Sachchai has particularly appealed to women. More than ninety percent Sachchai believers were women. ${ }^{6}$ Women also have a significant presence in leadership positions in the organization. Among women believers, those from low-caste and poor backgrounds constitute the majority. In my conversation with them, some nonbelievers, especially upper-caste women, characterized Sachchai as a 'low-caste religion.' Such characterization and the overwhelming majority of Dalits in Sachchai had primarily aroused my research interest in Sachchai. The attendees at Asha's branch where I happened to observe for the first time during my fieldwork were mostly Dalit women. During the course of my fieldwork, I observed a gradual increase in uppercaste women's presence in the movement, but not in the satsang at Asha's branch. And, by the end of my fieldwork, upper-caste women had a significant presence in Sachchai. Yet, Dalit women still held the majority: they led a significant number of Sachchai branches and the majority of leaders in the movement were Dalit women. The Sachchai group which I studied, Sachchai Kendra Nepal, was started and led together by a Dalit man and his upper-caste Brahmin wife, both in their late thirties. ${ }^{7}$

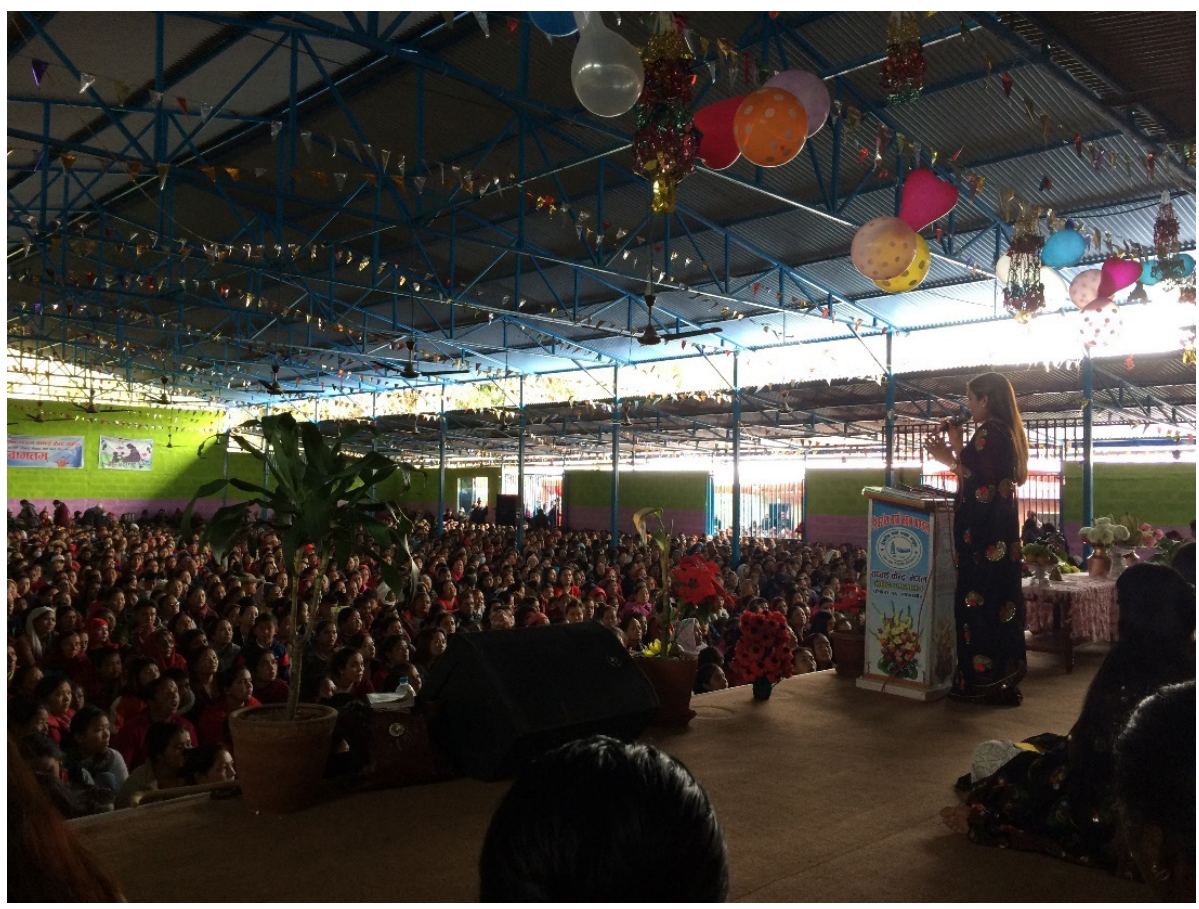

Fig. I:A Satsang of Sachchai Kendra Nepal. Pokhara, 2019

Sachchai claimed to address the problems of its believers such as illnesses and diseases, pain and suffering, household economic difficulties, family fights and misunderstandings, children's poor performance in school exams, poor productivity of crops and cattle, and so on. Yet, the majority of women mainly embraced Sachchai for three key reasons: healing their illnesses and diseases, repairing relationships with their husbands, and improving their household economic status. Bible study, speaking 
in tongues (glossolalia), belief in the Holy Spirit, and prayers were key elements of addressing the problems. Although Sachchai believers studied the Bible, they denied that they were Christians and disliked being associated with any form of Christianity. Sachchai believers were allowed to hold on to their previous religious and cultural practices, rituals and festivals. ${ }^{8}$ But the believers were discouraged from worshipping Hindu gods, visiting temples, shamans, and oracles.

\section{Learning to Speak}

To my question of what was the biggest achievement of Sachchai, nearly every Dalit Sachchai woman (including leaders and ordinary believers) I spoke with, either said they 'learned how to speak', or 'became able to speak' through Sachchai. When I further asked what they specifically learned, the responses were varied: Some said they now had confidence to talk to strangers, others said they could now confidently introduce themselves to strangers, to high-status persons, or in public gatherings, and still others said they could now deliver a speech at a public gathering. Before joining Sachchai, they said they feared speaking both at home and in public. Many of them said they did not even know how to tell their name (nam bhanna ni aaune thiyena). So, for many of these women, even speaking out their name through a microphone and just uttering some words before an audience was a great achievement.

Their admission that they could not say their name was not just symbolic. It had literal meanings, for two reasons. First, I assume that the understanding of what is a proper introduction was largely shaped by Nepal's development discourse. In my own observation, women's literacy classes held in the 1990s would teach them to introduce themselves. I recall how my mom, who was then in her sixties, practised introducing herself. Second, many of my interlocutors felt uncomfortable just to pronounce their name in public. I asked Maya why. Like the majority of Dalit Sachchai believers, she did not go to school and her formal name was seldom used by her family and in her village. Everybody in her family and village called her by the nickname kanchhi, a name commonly given to the youngest daughter in a family. Kanchhi was not considered a proper or formal name, but since Maya mostly engaged in domestic work, she did not need to use her official name. And, whenever she had to introduce herself to a stranger, Maya would find it uncomfortable to use her formal name. People in villages were called through names derived from kinship relations. Instead of using her proper name, a woman would be referred to as someone's daughter, or as someone's wife, or as someone's mother, or as her birth rank in the family. This is still widely the norm in Pokhara and surrounding villages. Additionally, Dalits often used to get derogatory names mostly drawn from their caste and other features such as skin colour, height, and weight. ${ }^{9}$ One recent anecdote shows how just being able to speak is still important for Dalit women. Punam Yadav, (2016) who conducted fieldwork in the early 2010s among women of her native village in southern Nepal said that, 'Women of this lower caste community, whose names were hardly known to anyone, are now introducing themselves by their own names.... This is the community where women were banned from going to a literacy class just a few years ago (p. 164).

Just being able to speak was not only important for Dalit women but also for upper-caste women. Saubhagya Shah (2018) conducted ethnographic fieldwork in the 
late 1990s among members of Women Development Section, a women's organization in Eastern Nepal formed and supported by the United Nations' Food and Agriculture Organization. In evaluating the impacts of the project, he writes (p.206):

When asked to identify the most significant contribution of the WDS for local women, the activists invariably say that it provided a forum where they could find their voice. Haimi lai kam se kam bolna sakne banayo - it made us at least able to speak - this is how they evaluated the project's impact. Before they had their organization, the women say, they did not know how to speak in public and that they were shy and hesitant to take up public issues.

Shah notes that although the project aimed to support women from low-income households, women's learning of how to speak was an important byproduct. This anecdote shows how even upper-caste women ${ }^{10}$ could not speak in public and how they required many years of external, international organizations' support to learn how to speak.

Nonetheless, Sachchai women now had become more confident about speaking with strangers. During my fieldwork Dalit Sachchai women readily accepted my request for a conversation and an interview with them. I met and interviewed many of my interlocutors outside their homes, in restaurants, tea shops, and in their businesses. They were much franker and more forthcoming than I had expected. A few women initially showed some hesitation by conceding that they did not how to talk (kura garna aaudina). But eventually, as they spent more time with me and became more comfortable, they spoke very well. Otherwise, an average Nepali woman, as I observed during my visits to Pokhara, would remain hesitant to speak to a stranger, especially a male. Many Dalit Sachchai women mentioned their interaction with me as an example of their confidence in speaking that they achieved through Sachchai. They acknowledged that they would not have had such confident conversations with me had they not embraced Sachchai.

How did Sachchai help to boost women's confidence and to learn and practise speaking? First, speaking was central to Sachchai's healing process. Slogans such as 'testimonies are medicine' (gabaile dabai hunchha), and 'the more one speaks, the more an evil spirit is hurt (jati bolyo uti dusta lai polyo), that Sachchai women often invoke, highlight the importance of speaking in Sachchai healings. Every satsang participant got an opportunity to narrate their testimonies, conduct prayer meetings, and sing songs. Additionally, unlike in some Pentecostal groups, ${ }^{11}$ Sachchai offered women leaders and believers (including Dalits) an opportunity to give edifying speeches. In every satsang, at least half a dozen women volunteered to narrate their testimonies, give edifying speeches, and sing devotional songs. Even when a woman was holding a prayer session or singing a song, she would usually deliver a brief speech. A typical satsang sequentially comprised the following activities: an initial prayer conducted by a woman; one or two bhajans; five to seven testimonies by different women; one or two devotional songs; five to seven edifying speeches by different women; one or two devotional songs; edifying speeches by both main and deputy leaders of the branch, one or two devotional songs; and a final prayer by one woman, and lastly one or two devotional songs. The satsangs were held thrice a week in the centre (central place 
or hub) and twice a week in most branches. Many women in Pokhara attended all the weekly satsangs at both places. Speaking at the centre's satsang that was usually attended by about 2500 to 3000 believers was considered a remarkable achievement for any Sachchai woman believer.

Second, Sachchai, with its empathetic listeners, provided a community of social and emotional support to comrades in turmoil. The emotional support from fellow believers became crucial for building confidence for a newcomer. Believers encouraged a hesitant woman to take the microphone and speak to the audience. When a woman would finally stand up to speak but mumbled, or could not find words to speak, or could not hold the microphone properly, those sitting near her helped. They would hug a trembling woman and provide physical support, help her to hold the microphone, and guide them on what to say next. When a lady could not speak, she would often, as I observed, tell her testimony to another woman who, in turn, conveyed it to the audience. The audience did not deride a mumbling woman. Instead, they provided emotional support by cheering and applauding every word or sentence that she uttered. Thus, the love, care, and support a woman received from fellow members helped build her confidence in her ability to speak.

Sachchai women thus, found a community of listeners, who heard their speeches compassionately and identified with them. These women told me that they had never been heard by anyone in their families and neighbourhoods, and that they had finally found some people in Sachchai who heard them. Having someone who hears one's pain and suffering is healing itself. But theoretically, as scholars have argued, an act of speaking becomes unsuccessful if it is not heard in the intended way. With regard to her famous question, 'Can the subaltern speak?' Gayatri Spivak (1992) points out the importance of subaltern voice being heard: 'When you say cannot speak, it means that if speaking involves speaking and listening, this possibility of response, responsibility, does not exist in the subaltern's sphere' (Spivak, 1992, p. 42). She suggests that even if subalterns speak, they are not heard. Spivak's assertion rings true when Sachchai women said they were not heard by anybody, even when they spoke.

Thirdly, Dalit Sachchai women said that they spoke in accordance with God's instructions and support. God was supposed to speak through the believers' mouths, and every word a believer uttered was supposed to be God's word. In a way, this is both an acceptance of paternalism as well as an articulation of the embodiment of voice that transcends gender. Additionally, God was a key source of inspiration, confidence, and legitimacy for the things that the women said when they spoke. One day, I asked Asha how she learned to speak in Sachchai satsangs. She answered, 'God has told us, "You [woman] can speak. You Dalit women can speak. I have chosen you to speak. So, don't fear my children. I am here to help you." She claimed that her new God, Jesus Christ, had chosen Dalit women because they were the most oppressed people in society, and he wanted to begin his mission of social transformation with Dalit women. According to Asha, her speech was 'directed' by God. Believers, during their speeches, would generally make a disclaimer that whatever was spoken was according to God's will, not their own will. When a woman stood up for the purpose of speaking, but mumbled or could not find words to speak, it was interpreted by the other believers that God did not want her to speak at that moment. She was consoled by saying that God would 
bring her the words later when he wanted to speak. The burden of speaking was placed on God, and this served as an effective tool both to encourage women to speak and to legitimize what they said.

Sachchai women equated their speaking with that of a child who has just begun to learn the language. They considered themselves as children of God and their embracing Sachchai as a new birth into the divine world. 'How long has it been since you became a child of God?' they often asked fellow believers. Thus, a Sachchai believer was supposed to learn and practise speaking the 'new language.' God was believed to be teaching them how to speak in the same way as parents teach their children how to speak. 'I am just a five-year-old child of God. How does a five-year-old child speak? You know it. My speech is like this.' This was how some women would relate their progress in learning to speak to fellow members in satsangs. Such statements were a modest expression of praising their own speaking skills while acknowledging that they were still on the learning curve. Sachchai women often characterized their past saying, 'In the past (in the earthly life), we were dumb. We had mouths, but we could not speak.'

What do these women speak in the satsangs? Sachchai women usually explain the pain and suffering they underwent, the status of their healing, and encouragement to other women based on their experience and learning. Those who give an edifying speech, additionally explain passages from the Bible. They pick a passage and explain it based on their understanding and life-experience, with examples and illustrations. They implicitly critique the sources of their suffering and pain, the structures of power and domination, and injustice and oppression they had to undergo-but all from a divine perspective. They explain their illness, pain, and suffering as consequences of the influence of an evil spirit. As Evans-Pritchard's famous insight about Azande belief in witchcraft (1937) reminds us, blaming an evil spirit for their illnesses, pain, and suffering does not mean that they do not know the real cause. The women's speeches revealed that they knew it very well. Even I am aware of this fact, and my analysis has focused on what they think, say, or claim. However, I choose to focus on what they valued and why.

\section{Holding the Microphone}

We now discuss the significance of the microphone in this movement. 'You all will speak through this microphone one day,' asserted a Sachchai leader in a satsang. Believers raised their hands above their heads and clapped in agreement. The leader solicited the believers' responses to her series of questions: 'Do politicians have the exclusive right to speak through a microphone?' 'No.' 'Do men have the exclusive right to speak through a microphone?' 'No.' 'Do educated persons have the exclusive right to speak through a microphone?' 'No.' 'Everyone can speak through a microphone.' 'Yes. Everyone can.'

The leader, then, raised the microphone and said, 'this microphone belongs to you all, come grab it and speak.' She urged her fellow women believers to abandon their fear, to build confidence, and to speak through the microphone in Sachchai satsangs. Reminding them what God said about fear in the Bible, she explained why fear was the main source of suffering and why one should abandon fear in order to heal. In the 
Sachchai worldview, evil spirits can easily hurt those who are weak and full of fear, and such evil spirits are only defeated by being strong and confident. Thus, the leader assured fellow believers that their fear of speaking would vanish one day and that they too would be able to come forward and grab the microphone. For Sachchai women, speaking through the microphone symbolized courage, confidence, and power - the main weapons for defeating evil spirits. Being able to speak through a microphone was considered a sign of healing.

Furthermore, by invoking the idea that it is also the right of women, illiterate, and common people to speak through a microphone, the leader indicated the symbolic power of a microphone. For the leader and other believers, the microphone symbolized prestige and empowerment. It follows that women who had similar educational, economic, and caste backgrounds to those of the majority of Sachchai women, but who were denied access to microphones, were denied prestige, status, and power. Outside of Sachchai, speaking through a microphone was a privilege mostly enjoyed by men, especially educated men and politicians. Public meetings in Pokhara, and in Nepal in general, are generally held in a highly hierarchical fashion. Seating is arranged in such a way that high-status guests are seated on special chairs on an often-elevated dais while others are seated at ground level. Those seated on the dais are called upon to sit in an order based on their ranks. The order of who speaks first and who speaks next is also determined according to a person's status or rank based on occupation, official position, and so on. ${ }^{12}$ The lowest-ranked person speaks first while the highestranked person speaks at the end of the meeting. Hierarchy is occasionally contested resulting into controversies and fights. Thus, any public meeting in Pokhara serves as a platform to display status, prestige, and power. Speaking through a microphone while standing on a dais before an audience has given a sense of worth, status, and prestige to Sachchai women.

This 'status symbolism' of microphone in Nepal may be one reason that Sachchai women initially felt uncomfortable while speaking through a microphone. During my fieldwork, I observed that many women are hesitant to go to the dais and tell their testimony through a microphone in Sachchai satsangs. They would refuse to do so despite repeated requests from Sachchai leaders. They rather chose to tell their testimonies from the floor level without a microphone, confessing that they would feel shy about speaking through the microphone.

One day, I visited a Dalit Sachchai woman, Kalpana, in her garment stall in a market complex. We talked about her testimonial speech that she had delivered the previous week in an 'international' satsang held in Pokhara. Brimming with self-pride, she said, 'since I addressed such a big crowd attended by such "big" persons, there is nothing now that I may not be able to do. I think I can do whatever tasks I may need to do' (aba maile garna nasakne bhanne kei kura chhaina. Je kura pani garna sakchhu jasto lagchha). The Sachchai Kendra had organized an international satsang in the summer of 2018 in Pokhara. It was attended by more than twenty thousand Sachchai believers and leaders from across the country and from India and the USA. Nepal's Deputy Prime Minister cum Health Minister was the chief guest. Kalpana delivered her testimonial speech in the satsang which became proof of her courage and power. That courage and power is not just related to her speaking. She believed that she could now solve or deal with any kind of problem she may encounter. She was given just five minutes to deliver her testimony. But for her speaking through the microphone for 
those five minutes became her greatest achievement and the evidence of her inherent courage and power.

Speaking through a microphone, therefore, held special significance for Sachchai leaders and believers. They stressed upon not just their ability to speak but to speak through a microphone. "Mike ma bolna sakne bhaye" (I was able to speak through microphone) was a response many women gave me when I asked them what they gained through Sachchai. During my conversations with them, Sachchai leaders and ordinary believers often spoke with pride about their abilities to speak through a microphone and considered such speaking as proof of Sachchai's legitimacy. 'Did you see how women in Sachchai satsangs speak through microphone?' Sachchai women often asked me. Some non-believers with whom I interacted also appreciated the confidence of Sachchai women to speak through microphones. Even die-hard critics of Sachchai admitted this as a great achievement for Sachchai and its Dalit women believers. An upper-caste Hindu man who was a vocal critic of Sachchai and had posted a video on YouTube accusing Sachchai for supposedly 'Christianizing' Nepal attributed the popularity of Sachchai among women to 'illiteracy, poverty, and foreign money.' These are common allegations of upper-caste Hindus against Sachchai. Admitting that his wife had also briefly embraced Sachchai, he cited two genuine reasons for attraction of women toward Sachchai. One reason, he claimed, was Sachchai's declaration of caste equality which appealed to low-caste women. The other was 'Sachchai's offering of respect to women by giving them microphones.' He however said that women should not 'convert to Christianity' just for having the opportunity to speak through microphones.

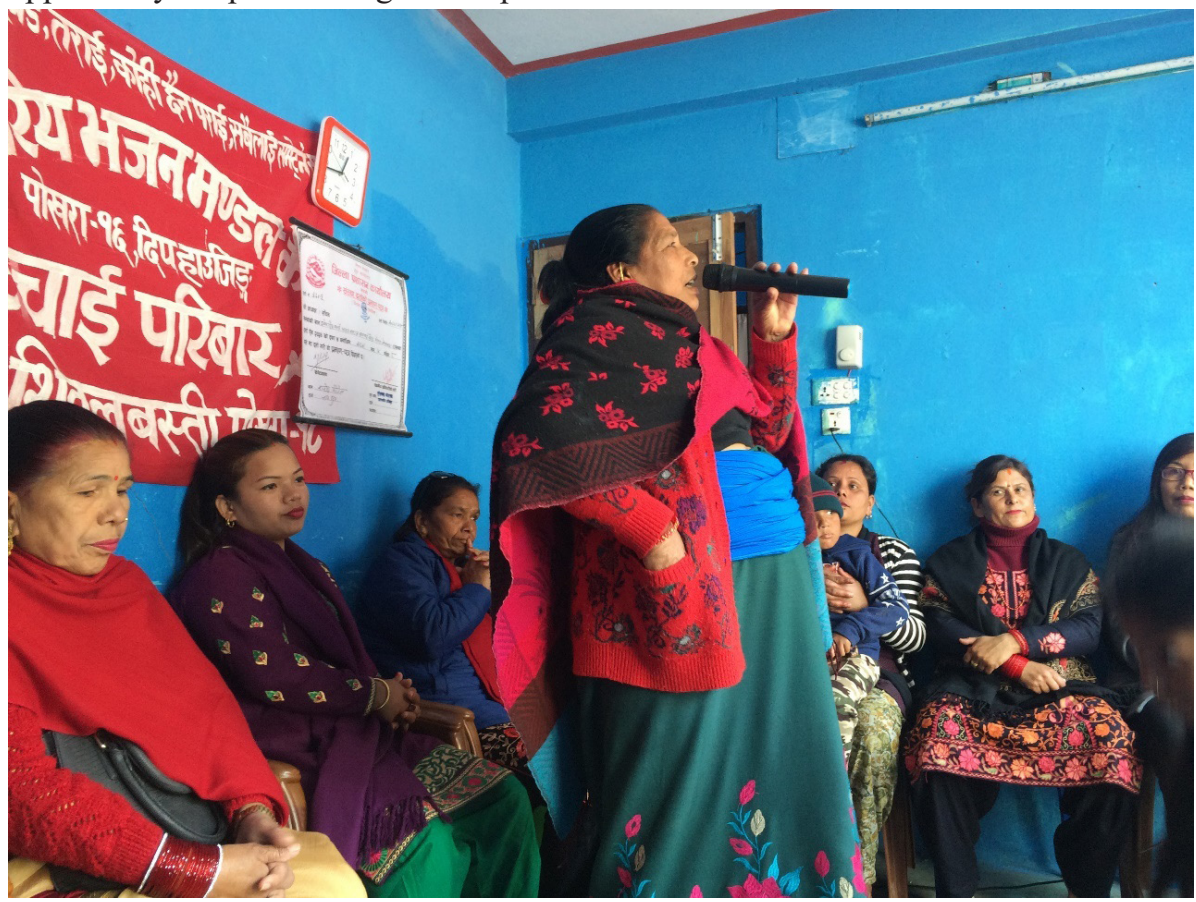

Fig. II: A Dalit Sachchai Woman Giving an Edifying Speech in a Branch's Satsang. Pokhara, 2019 
Microphones did not just amplify sound to make a speaker audible to the audience. And, they did not just symbolize confidence and empowerment as discussed. They also served aesthetic functions that Sachchai leaders and believers did not explicitly acknowledge. On the one hand, the theatrical and entertaining sound produced by the microphones and loudspeakers served as a means to attract believers. Loudspeaker sounds in satsangs were often deafeningly loud. When I asked Asha why she used the microphone in her branch even if the audience could hear the orator without the speakers, she simply answered that her sisters, i.e. fellow women believers, liked to speak through the microphone. Although she did not mention it, one possibility is that the Sachchai speakers actually liked the aesthetic function of the loudspeaker's sound. This aesthetic function of sound in charismatic healing movements such as Pentecostalism has been well acknowledged by scholars.

On the other hand, the loud sound produced by the loudspeakers served as a tool to reach out to non-believers. The aesthetic function of sound and speeches that scholars such as Birgit Meyer (2010) noted also helped to attract non-believers, especially in Nepal where reaching out to non-believers in other ways was challenging given the stringent anti-conversion and anti-proselytizing laws. ${ }^{13}$ In other words, the highly amplified sound and emotional speeches served as a tool for evangelizing. This could be one reason why the volume of the loudspeakers was kept high and why the loudspeakers were positioned facing outward from the satsang buildings. Most Sachchai buildings were not sound-proofed: some centres did not have any wall or, were not adequately walled, and others were half-walled. Satsangs in many village branches were held in courtyards. In any case, the sound from the loudspeakers easily escaped through the sastang venues so that Sachchai women's neighbours and other strangers could hear they said. A loudspeaker might be essential in larger satsangs to make the speaker's sound audible to the entire audience, but it may not be required in smaller meetings. Yet, microphones and loudspeakers were used even when an audience could listen to a speaker without a loudspeaker. Yet, most of the village branches, attended by less than 30 or 40 believers, used loudspeakers. Additionally, Sachchai branches held their annual congregations mostly in public places, often attended by lots of people. I observed an annual satsang of a branch in Kathmandu which was held in a public lawn at the middle of a busy intersection. The fence around the lawn, in every direction, was tightly packed with a public audience and people from shops and houses around the lawn were also watching the satsang.

\section{Speaking is Healing}

'God made me able to speak standing before you all, this is my biggest testimony.' I heard many women say this in satsangs when they stood to speak about their experiences or give edifying speeches. Initially, I could not make a sense of this claim. Some women said they had been so severely ill that they never thought that they would ever again be able to stand on their own or be able to utter words. 'But when I heard more of these testimonies and paid close attention to what they said about their illnesses after they had recovered, I began to understand why they considered their speaking in the satsang as proof of their healing,' said one of them. These women had been rendered virtually speechless and silenced by their families and societies, especially when they had conflicts with their husbands and in-laws, or when they had health issues, mainly depression. They had been ostracized, had no confidence 
to speak and no one listened to them. This was why speaking at a satsang to an eager audience came to be cherished by them.

Even when women were not seriously ill or did not have conflicts in family, in a Hindu family in Nepal a married woman is not usually allowed to speak out her mind or talk to her neighbours and share her feelings and family issues with them. A husband's family would fear that she would reveal family secrets to neighbours and relatives. Also, a mother-in-law would not want her daughter-in-law to spend time talking to her husband, lest she would wean him away and stop supporting the family financially if he got close to his wife (see Bennett, 1983). Des Chen (1998) details how a married woman - known as bhauju in Nepali-whose husband lived in India, was not allowed by her mother- and father-in-law to talk with her neighbours. The married couple's daughter always accompanied the married woman to ensure that she would not disclose any family matters or suffering inflicted by the family to her neighbours. Bhauju was a middle-caste woman and Bennett's interlocutors were upper-caste women. But the patriarchal norms that restricted bhauju and upper-caste women from speaking with others had equally permeated Dalit lives as well. Kalpana, the Dalit Sachchai leader whom I introduced earlier, told me that she was similarly accompanied by her husband's family members when her husband was living abroad. She said that her father-in-law neither gave her letters her husband sent to her, nor told her when her husband called for her on the phone. Furthermore, her in-laws used to get angry when she spoke to any men or women in the village. Thus, a married woman in the Nepalese society seldom had a chance to talk with others, let alone share her suffering and pain.

One main reason why many women joined Sachchai was the isolation they faced as a result of abuse and violence from their husbands and their families, severe illness (mostly depression), and their ostracization from family and neighbours. Many Sachchai women characterized their condition as equivalent to a bug that lives in a swamp (naliko kira): 'My life was like a bug that lives in a swamp, no one cared about me. I was discarded and ostracized by my family,' they would say in their testimonies.

I again refer to Asha's example, which shows how speaking was significant to her in light of social and family ostracizations and her long battle with depression. Asha became seriously ill for seven years after she gave birth to her third child. She suffered from what is called depression in medical terms, but Hindu astrologers and shamans suggested that she had been possessed by a goddess (devi chadeko). She accepted the diagnosis of the shamans and proceeded by building a temple in her home, observing strict fasting, and performing worship. Her neighbours accused her of being a witch and cut off interactions with her. She was ostracized from her family and neighbours and was treated like dirt.

Then Asha heard of Sachchai and attended a satasng. When she saw other suffering women speaking through a microphone, she said she dreamed of speaking like them. Within two weeks, Asha spoke into the microphone, sang a song and danced, and spoke about her illness. That was the first time she had ever spoken through a microphone and shared her suffering and pain in front of a mass of interested people. She said no one in her family or neighbourhood was interested in listening to her, but in Sachchai she found people who would listen to her. As her story reveals, women's immediate 
cause for according value to speaking comes from being unheard by anyone in their own families and neighbourhood. Their feeling of neglect, ostracization, and lack of opportunity to say what they feel like is the immediate cause of their yearning to speak.

The second reason for embracing Sachchai was caste and patriarchy which had brutally suppressed their sound and voice, and the new faith gave them a chance to speak. I now present a story of another Dalit woman which illustrates the larger structures of caste and patriarchy that provide the contexts to the Sachchai women's desire to speak. Into her fifth year in the movement, Pushpa had now become an eloquent orator. A woman in her late twenties, Pushpa had finished her undergraduate degree, unlike other girls in her community, and was working as a housekeeper in a hotel in the town. It was a job that was unrelated to her degree, and paid poorly. Pushpa belonged to a traditional caste of singers - the lowest among low castes - whose males eked their living by wandering around villages singing songs and playing the fiddle in return for food and money. In addition to entertaining people by singing they would also serve as newsmongers spreading local news, messages, stories, myths, and events about recent incidents through their songs (See, Weisethaunet, 1998). For these tasks, they would need a good voice as well as awareness about news and incidents to survive. But their women stayed home; they would not travel.

I met and interviewed Pushpa one summer evening. She initially went to Sachchai not for herself, but for her father's illness. Upon hearing Sachchai women's exciting speeches there, she decided to embrace the movement. From her childhood, she had always wanted to speak, but had lots of inhibitions. She would hide when someone came to her home and never spoke a word in her school. She described herself before joining Sachchai in the following words:

I would be shy to just sit among a few people. If I attended a wedding ceremony, I always wanted to avoid sitting with people. I used to be too shy to dance. People needed to pull me by my arms to force me to dance, and sometimes I felt like my arms were going to detach from my body. Now, I don't feel shy at all. I can put up with any kind and any number of people. Now, I dance spontaneously. Nobody needs to request me or force me. Now when I listen to a song, my legs start shaking reflexively. Why should we fear? A week after I joined Sachchai, I sang a devotional song. In the following week I narrated my testimonial and a few weeks later, I was able to teach the Bible. I don't know how I got that courage.

Why did Dalit Sachchai women, like Asha and Pushpa, desire so much to speak? What do they achieve from their speaking? As the cases of these two women show, Dalit Sachchai women realize self-worth, self-respect, and a sense of empowerment. Within Sachchai, they get appreciation and respect from fellow women, get recognition and status as a leader, and get invitations to speak from other branches. Outside of Sachchai, their husbands, husbands' families, and neighbours begin showing some level of respect to them. To reiterate, it is only the high-status and powerful people who speak in Nepal.

Dalit Sachchai women's desire to speak becomes more understandable within the larger contexts of Nepal. Speaking was an important marker for women and men in Nepal especially after the 1990s. The decades after 1990 in Nepal has seen a surge in 
citizens' desire to speak in the public sphere, as being able to do so represents freedom, modernity and political claims. The fall of autocratic monarchical rule and introduction of limited democracy in 1990, the subsequent growth of public media such as radios and newspapers, empowerment programmes run by the state and other development agencies, and the rise in overall literacy rates - all these factors emboldened and contributed to actualizing that desire. Public voice acquired enormous significance in post-1990s Nepal, as political voice was supposed to be required to fight for and sustain democracy and to achieve the country's development and modernization (Kunreuther, 2014). These decades also saw a significant rise in women's as well as other marginalized groups' voices for their rights, equality, and justice. Dalit Sachchai women's desire to speak may have been shaped by these discourses around freedom, modernity, and selfhood.

\section{Conclusion}

The ethnographic examples presented in the previous sections have, I hope, shown why just being able to speak through a microphone and standing before an audienceirrespective of what they said - mattered so much for the Dalit women I studied. Their speaking through a microphone mattered to them so much so that it signified their condition of being healed from illnesses, pain, and suffering. Why did these women give so much value to such 'ordinary' acts such as uttering some words, holding a microphone, or standing and speaking before an audience? It is because, as I showed in this article, these women had been brutally silenced, both in their families and society. Many women said that once upon a time they had even hesitated to just utter their names, or to introduce themselves to others, or hold conversations with strangers or high-status officials. Besides enduring silencing norms of patriarchy and castes, these women became mute because of their immediate condition of ostracization, disrespect, and abandonment by their husbands, husbands' families, and neighbours. Under such circumstances, they neither had confidence to say what they wanted to say nor found someone who would hear what they had to say. Sachchai gave them a platform to speak; the women thus realized some degree of worth, self-respect, and power through their interactions and exposure in the movement.

I have shown that the speaking of Dalit Sachchai women did not just serve as a means of conveying a religious message - a communicative function, as scholars of religion have argued. Dalit Sachchai women's speaking is an end in itself that produces a kind of embodied empowerment and fulfils their desire to speak. Similarly, I have shown how paying attention to speaking itself-irrespective of its contentcan enhance our understanding of voice. This aspect of voice, the speaking, has been ignored by scholars who have studied voice, including those from feminist, subaltern, and Dalit studies. As I discussed in the introduction of this article, voice is generally taken for granted and is mostly understood as an index to agency and empowerment.

While focusing on the act of speaking, this article, however, does not minimize Dalit Sachchai women's agency and empowerment, or the emancipatory potential that the act of speaking signifies. These women's utterances certainly contain much political potential and their speaking has surely brought many micro-level changes in terms of 
gender relations in their lives. Speaking in Sachchai satsangs is, to a certain extent, an act of resistance to the patriarchal and caste structures that silenced their voice. Although my examples clearly suggest the agentive potential, I have not explored this in the article. For this reason, what I have presented here is just a half story. I did not focus on the other half of the story which is the agentive element of the women's speaking, because other scholars have paid ample attention to it. For example, Saba Mahmood (2005) has famously revealed agency among women who participated in Islamic piety movements in Egypt that aimed to cultivate Muslim ethics. Closer to home, Nathaniel Roberts (2017) has eloquently shown how Dalit Pentecostal women in Chennai, South India, used their suffering 'as a tool of social suasion'. He terms such an agency as 'agentive suffering.' What I have focused in my article is the women who I studied, and what they most often commented upon.

This article intended to expose the condition of a section of women, specifically Dalit women, for whom just uttering their name in the public was a great feat. While other sections of women in Nepal are much more outspoken and empowered, and have even become radical and revolutionary agents of transformation (For example, See Lohani-Chase, 2008; Manchanda, 2004; Pettigrew \& Shneiderman, 2014; Yadav, 2016). My article has shown a contrasting picture to the celebratory portrayal of Nepali women seen in these studies. For the women I studied, raising a voice for political rights is very far from reality. Instead, just being able to speak - to say their own name in public, to utter some words loudly, to talk to a stranger-is what mattered most to these women.

\section{Acknowledgments}

I am deeply indebted to Joseph Alter, Sunaina Arya, Adhyata BK, Dhakmaya BK, Patrick Beckhorn, Nicole Constable, Steve Folmar, Prakash Deep Gaire, Ashok Gurung, Sharmila Sunar, the editors of the journal, Caste: A Global Journal on Social Exclusion, and anonymous reviewers for their comments and other support. I am also indebted to the leaders and believers of Sachchai Kendra Nepal for their time, trust, and support during my fieldwork. An earlier version of this article was presented at the Fifth International Conference on the Unfinished Legacy of Dr. B.R. AmbedkarDalits in Global Context: Rethinking Gender and Religion in October 2019 at the New School, New York. I am grateful to the conference organizers and panel discussants and participants who provided constructive comments on my paper.

\section{References}

Arya, S. (2020). Dalit or brahminical patriarchy? rethinking Indian feminism. CASTE: A Global Journal on Social Exclusion, 1(1), 217-228.

Bennett, L. (1983). Dangerous wives and sacred sisters: social and symbolic roles of high-caste women in Nepal. New York: Columbia University Press.

De Vries, H. (2001). In media res: global religion, public spheres, and the task of contemporary comparative religious studies. In H. De Vries \& S. Weber (Eds.), Religion and Media (pp. 4-42). Standford: Standford University Press. 
Des Chene, M. (1998). Fate, domestic authority, and women's wills. In D. Skinner, A. Pach, \& D. Holland (Eds.), Selves in times and place: identities, experience, and history in Nepal (pp. 19-50). Lanham: Rowman and Littlefield Publishers, INC.

Dunn, L., \& Jones, N. (1994). Introduction. In L. Dunn \& N. Jones (Eds.), Embodied voices: representing female vocality in western culture (pp. 1-33). Cambridge: Cambridge University Press.

Evans-Pritchard, E.E. (1937). Witchcraft, oracles and magic among the Azande. Oxford: Clarendon Press.

Gibson, I. (2017). Suffering and hope: Christianity and ethics among the Newars of Bhaktapur. Kathmandu: Ekta Books.

Guru, G., \& Sarukkai, S. (2019). Experience, caste, and the everyday social. New Delhi: Oxford University Press.

Hertzog, E. (2011). Patrons of women: literacy projects and gender development in rural Nepal. New York and Oxford: Berghahn Books.

Hirschkind, C. (2006). The ethical soundscape: cassette sermons and Islamic Counterpublics. New York: Columbia University Press.

Jørgensen, J.A. (2008). Jesus Imandars and Christ Bhaktas: two case studies of interreligious hermeneutics and identity in global Christianity. Frankfurt: Peter Lang.

Kunreuther, L. (2014). Voicing subjects: public intimacy and mediation in Kathmandu. California: University of California Press.

Lohani-Chase, R. (2008). Women and gender in the Maoist People's War in Nepal: militarism and dislocation. (Ph.D.). Rutgers, The State University of New Jersey,

Mahmood, S. (2005). Politics of piety: the Islamist revival and the feminist subject. Princeton: Princeton University Press.

Manchanda, R. (2004). Maoist insurgency in Nepal: radicalizing gendered narratives. Cultural Dynamics, 6(2/3), 237-258.

Meyer, B. (2010). Aesthetics of persuasion: Global Christianity and Pentecostalism's sensational forms. South Atlantic Quarterly, 109(4), 741-763.

Pettigrew, J., \& Shneiderman, S. (2014). Women and the Maobadi: ideology and agency in Nepal's Maoist movement. Himal South Asian, 7(1), 19-29.

Robbins, J. (2004). The globalization of Pentecostal and Charismatic Christianity. Annual Review of Anthropology, 33, 117-142.

Roberts, N. (2016). To be cared for: the power of conversion and foreignness of belonging in an Indian slum. California: University of California Press.

Roberts, N. (2017). Transformation and the suffering subject: caste-class and gender in slum Pentecostal discourse. In S. Anandhi \& K. Kapadia (Eds.), Dalit women: vanguard of an alternative politics in India (pp. 280-304). London and New York: Routledge.

San Chirico, K. (2014). Between Christian and Hindu: Khrist Bhaktas, Catholics and the negotiation of devotion in the Banaras Region. In C. M. Bauman \& R. F. Young (Eds.), Constructing Indian Christianities: culture, conversion and caste (pp. 23-44). New Delhi: Routledge.

Shah, S. (2018). A project of memoreality: transnational development and local activism. Kathmandu: Himal Books.

Shrestha, U. (2000). Changing patterns of personal names among the Maharjans of Katmandu. Names, 48(1), 27-48. 
Spivak, G.C. (1992). Interview with Gayatri Chakravorty Spivak: New nation writers conference in South Africa. ARIEL: A Review of International English Literature, 23(3), 29-47.

Taylor, J. (2009). 'Speaking shadows': a history of the voice in the transition from silent to sound film in the United States. Journal of Linguistic Anthropology, 19(1), 1-20.

Toffin, G. (2016). Neither statuses nor ritual: an analysis of new religious movements and therapists in Nepal. In D. N. Gellner, S. L. Hausner, \& C. Letizia (Eds.), Religion, secularism, and ethnicity in contemporary Nepal (pp. 115-149). New Delhi: Oxford University Press.

Weidman, A. (2006). Singing the classical, voicing the modern: the postcolonial politics of music in South India. Durham: Duke University Press.

Weisethaunet, H. (1998). The performance of everyday life: the Gäine of Nepal. Oslo: Scandinavian University Press.

Yadav, P. (2016). Social transformation in post-conflict Nepal: a gender perspective. London: Routledge.

\section{Endnotes}

1 All names are pseudonyms.

2 Patriarchy in South Asia is dictated mostly by caste, and patriarchy can be termed more precisely as Brahminical patriarchy (see Arya, 2020).

3 Guru and Sarukkai (2019, pp. 60-66) state that in the past in India, the mere sound of a Dalit would pollute an upper caste, hence Dalits were not allowed even to produce sound in certain situations.

4 For an account of new religious movements in Nepal, see Toffin (2016).

5 For the origin of Sachchai, I interviewed Sachchai founders - an American man (living in the USA) and the other a Japanese man (settled and living in India) — when they had visited Pokhara to attend a Sachchai satsang. According to their accounts, they were part of an Indian mission of a Biblical group called The Way International founded in the USA in the early 1940s. After being dissatisfied with the evangelical group, they founded Sachchai in the late 1970s, as unorganized, family-based congregations so that a believer did not necessarily need to go to or become a member of a Church and also that a believer could study the Bible irrespective or his/her religious and cultural backgrounds.

6 This is not uncommon in the global context of charismatic Christianity, such as Pentecostalism, which is overwhelmingly participated by women (Robbins, 2004, p. 132). In Nepal, women outnumbered Pentecostal churches in Bhaktapur (Gibson, 2017).

7 Leading a religious group by an inter-caste couple in a deeply rooted caste society is itself significant in many ways. She sometimes used her Brahmin surname that clearly proclaimed her Brahmin status, and sometimes used her Brahmin surname together with the Dalit surname inherited from her husband that sounded like a Brahmin surname. Many believers knew their real castes, while some presumed both the couple to be Brahmins. But believers I interacted with were not concerned about the couple's caste identity, as they said, 'caste does not matter in the kingdom of God.'

8 This phenomenon in which Jesus Christ is followed while continuing to practice religions that were practiced before their introduction to Jesus Christ is evident in other parts of South Asia. For example, the Khrist Bhakta of Chennai, South India consider Jesus as an incarnation of the Hindu god Brahman (For example, see, San Chirico, 2014), and the 
Jesus Imandar of Dhaka, Bangladesh, follow Jesus Christ but continue to celebrate Muslim festivals(For example, see, Jørgensen, 2008).

9 Uma Shrestha (2000, p. 41) observed the 'abundance of kin terms ... used as personal names' among a low caste group in Kathmandu. She also observed younger generations' embarrassment for their first names that were derived from their caste.

10 The women researched and cited by Shah, no doubt, were upper-caste women. Dalit women had little access to development programs and, hence, they had little chance to learn how to speak, as compared to upper-caste women.

11 For example, Nathaniel Roberts mentions that in South Indian Dalit slum Pentecostalism, where 85 to 90 percent of believers were women, Pentecostal women were ineligible to be ordained as pastor and hence were 'confined to non-speaking and supportive roles' (Roberts, 2016, p. 207).

12 Hertzog (2011, pp. 182-184) provides an account based on her observation of a women's literacy training program. She finds that even for women's empowerment projects, all the speakers (except her) were (upper-caste) male while all the listeners were women.

13 Proselytizing is illegal in Nepal. One who proselytizes or assists in proselytizing is punishable by up to five years of imprisonment and up to fifty thousand Nepali rupees (roughly equivalent to USD500) fine. This law is murky, so that even the performance of baptism could be considered as converting or proselytizing. 